\title{
TTR
}

Traduction, terminologie, re?daction

\section{Decolonising Québec: Discursive Strategies in Michel Tremblay’s Mistero buffo}

\section{Jane Dunnett}

Volume 10, numéro 1, 1er semestre 1997

Langues, traduction et post-colonialisme

Languages, Translation and Post-Colonialism

URI : https://id.erudit.org/iderudit/037282ar

DOI : https://doi.org/10.7202/037282ar

Aller au sommaire du numéro

\section{Éditeur(s)}

Association canadienne de traductologie

ISSN

0835-8443 (imprimé)

1708-2188 (numérique)

Découvrir la revue

Citer cet article

Dunnett, J. (1997). Decolonising Québec: Discursive Strategies in Michel

Tremblay's Mistero buffo. TTR, 10(1), 137-164. https://doi.org/10.7202/037282ar

\section{Résumé de l'article}

Décoloniser le Québec : stratégies discursives dans le Mistero buffo de Michel Tremblay - L'un des procédés utilisés par un certain nombre d'intellectuels québécois des années 1960 et 1970 dans leurs efforts de mise en valeur de la cause nationaliste consista à exploiter la notion de décolonisation. S'inspirant des théories d'Albert Memmi et de Frantz Fanon, ces auteurs dénonçaient ce qui leur apparaissait comme un état de dépendance à la fois politique, économique et culturelle du Québec. Cet article analyse comment le topos de la colonisation qui imprègne le discours social de l'époque est intervenu au niveau de la traduction et de la réception de la version en joual de Mistero buffo fournie par Michel Tremblay. Il cherche également à démontrer que l'on a fait de la pièce de Dario Fo un instrument de remise en question de ce que l'on percevait comme une forme d'impérialisme culturel de la part de la France en même temps qu'un moyen d'affirmer l'importance de la phase de sécularisation qu'avait connue le Québec dans le mouvement de " décolonisation » où il était engagé.
Tous droits réservés (C) TTR: traduction, terminologie, rédaction — Les auteurs, 1997
Cest protégé par la loi sur le droit d'auteur. L’utilisation des services d'Érudit (y compris la reproduction) est assujettie à sa politique d'utilisation que vous pouvez consulter en ligne.

https://apropos.erudit.org/fr/usagers/politique-dutilisation/ 


\section{Decolonising Québec : Discursive Strategies in Michel Tremblay's Mistero buffo ${ }^{1}$}

\section{Jane Dunnett}

Even a cursory survey of Québécois social discourse ${ }^{2}$ dating from the 1960 s and 1970 s reveals an overwhelming preoccupation with the subject of colonialism. The present discussion is concerned with the manner in which this topic affected translation practices over the same period. Michel Tremblay's version of Mistero buffo (1973a) has been chosen to illustrate the extent to which the prevailing discourse on the economic, political and cultural colonisation of Québec was often incorporated into the target text. For, as Annie Brisset has pointed out :

${ }^{1}$ This article presents an idea which is part of a longer argument on the theme of colonisation and social discourse in Québec that I have developed elsewhere for publication.

2 The term "discours social" is employed by, amongst others, Marc Angenot (1989, p. 13) who offers the following, much quoted definition: "[...] tout ce qui se dit et s'écrit dans un état de société; tout ce qui s'imprime, tout ce qui se parle publiquement ou se représente aujourd'hui dans les médias électroniques. Tout ce qui narre et argumente, si l'on pose que narrer et argumenter sont les deux grands modes de mise en discours". 
On sait déjà que le matériau de la traduction ne se limite pas à la langue. Il n'est pas davantage constitué, de manière vaste et abstraite, par ce qu'on appelle la culture. C'est dans le discours social que la traduction opère, matériau préformé dont l'articulation présuppositionnelle assure la cohérence et l'intelligibilité des énoncés de surface. (1990, p. 252)

The translator, then, can be regarded as a social agent who necessarily draws on the doxa of a given society at a given time, reflecting certain assumptions whilst rejecting others, but always functioning within the frame of a pre-existing discourse.

Thus, before examining the text itself, I discuss briefly the historical and cultural context that provided the "horizon traductif" (Berman, 1995, p. 79) for Tremblay's Mistero buffo in order to gain some understanding of the way Québécois society viewed itself during the period in question. I begin by tracing the interest in decolonisation in general, and in the works of Albert Memmi and Frantz Fanon in particular, as well as the impact which these theories had on the Partipristes and on Pierre Vallières. Their attempt to find correspondences with the 'colonised condition' of the Québecois is examined. The desire to build a distinct national identity and to forge a new Québécois literary tradition is interpreted as part of the growing perception that a process of decolonisation was effective in the areas of religion and language. This is linked to the resurgence of a strong nationalist movement and to the founding of the Parti Québécois.

After contextualising Dario Fo's 1969 play, Mistero buffo, the decision to translate this text is assessed, and Tremblay's discursive strategies are explored through a textual analysis of several scenes where the topos of colonialism can be clearly discerned, a theme which provides a new ideological focus for the play. From Tremblay's version of Mistero buffo there emerges a binary world inhabited by the coloniser and the colonised whose confrontation is illustrated throughout the play. I investigate the way in which characters and events have been adjusted in the target text so as to coincide with various elements that make up the Québécois colonial universe, namely the literary use of joual as a weapon to challenge French cultural 'imperialism', the portrait of the subaltern and the portrait of the foreign master. 


\section{Decolonising Québec}

A central component in the 'revolutionary' ideas put forward by proindependence journals such as Liberté (1959-) and Parti pris (1963-68) was the notion of decolonisation. This term had initially been used in the 1950 s to describe the process whereby the colonised countries of Asia and Africa were gradually throwing off the yoke of foreign domination ${ }^{3}$, and a decade later it entered the vocabulary of Québec's Separatists.

For the Partipristes, decolonisation became one of the guiding principles which inspired their struggle to transform the province into "un État libre, laique et socialiste", as the first issue of their journal famously proclaimed ${ }^{4}$. When the review revamped itself in 1967 - changing format and focus to make itself a more appealing and predominantly political "mensuel d'information et d'analyse" - it foregrounded its commitment to what it called a "socialisme décolonisateur"s , where independence became synonymous with decolonisation : "lindépendance, l'étape décolonisatrice de la libération".

There was growing confidence that at least this stage in the Partipristes's social project was well underway, prompted no doubt by De Gaulle's recent visit to Montréal. The French President's celebrated cry of "Vive le Québec libre!" had strengthened their conviction that "le processus de décolonisation [...] s'opér[ait...] au Québec, depuis 1960" (Dumouchel, 1967, p. 27), a conviction they believed would now be shared by a growing number of Québécois citizens.

\footnotetext{
${ }^{3}$ It is perhaps worth pointing out that in the Asian and African contexts, the use of the generic term 'decolonisation' is regarded by some as suspect since it does not make clear whether the process has been set in motion by the colonised or by the coloniser. Such critics prefer the expression 'liberation struggles' (see, for example, Chamberlain, 1985). In the Quebécois context, however, the same problem of ambivalence does not arise, as the very notion that Quebec is a colony is rejected by the Federalists. In the mouth of the Separatists the term 'decolonisation' necessarily refers to a state of emancipation which they would have achieved by themselves.
}

4 "Présentation", Parti pris, 1, 1, October 1963.

${ }^{5}$ See Parti pris, 4, 5-6, 1967. 


\section{Theories of Colonisation}

Two seminal studies on the psychological and sociological impact of colonialism - Albert Memmi's Portrait du colonisé (1957) ${ }^{6}$ and Frantz Fanon's Les Damnés de la terre (1961) - circulated in Québécois intellectual circles from the early 1960 s onwards. Both denounced the oppression and racism on which colonial society is built, attacking its ideological and moral foundations, and both exposed the bad faith and double standards of the metropolitan rulers. They pointed to the way the latter had used - indeed, had institutionalised - mystification as yet another, even more insidious, weapon with which to maintain power. The mystificatory discourse which these regimes invariably produced was, according to this view, the cement that held the colonial edifice together. It sought to legitimise injustice and, at the same time, it served to undermine the indigenous people's self-esteem and thus, their capacity to resist the coloniser. As Memmi (1972, p. 92) puts it: "Être mystifié c'est déjà, peu ou prou, avaliser le mythe et y conformer sa conduite, c'est-àdire en être agi".

For the colonised subject is a construct, a figure whose identity is defined by the coloniser. By internalising the ideology of the dominant group, the individual ultimately embodies his or her own servitude :

Souhaité, répandu par le colonisateur, ce portrait mythique et dégradant finit, dans une certaine mesure, par être accepté et vécu par le colonisé. Il gagne ainsi une certaine réalité et contribue au portrait réel du colonisé. (Memmi, 1972, p. 88)

A similar phenomenon is described by Fanon in Peau Noire, Masques Blancs. He, too, observes this appropriation of reality by the coloniser who exerts a near-ontological control over the dominated 'other' (1952, p. 113). This vision of self imposed from the outside represents a loss of

\footnotetext{
${ }^{6}$ In 1963 , an abridged version containing only the section devoted to the colonised subject (from which the entire work derives its title) was published in the form of a pamphlet by the Éditions du Bas Canada, and distributed in Québec by l'Action Socialiste. The complete work, which also contained the Portrait du Colonisatew, was published in Montréal in 1972 with the preface by Jean-Paul Sartre from the original Parisian edition; clearly, interest in the subject of colonisation had not diminished in Québec.
} 
self, a psychological dispossession that stems from — and cruelly mirrors - the material dispossession of the colonised whose lack of selfdetermination condemns them to a perpetual state of alienation. According to Fanon (1952, p. 29): "Il n'y aura d'authentique désaliénation que dans la mesure où les choses, au sens le plus matérialiste, auront repris leur place".

It is not difficult to understand the appeal which such analyses must have held for the new generation of young, uncompromising intellectuals centred around Parti pris who had been influenced by Malraux, Camus and especially by the existentialist writings of Sartre, and were now exploring various forms of Marxism-Leninism which they attempted to apply to the Québecois situation. They found a theoretical framework for their militancy in a work such as Les Damnés de la terre, which stressed the historically determined nature of oppression and the need for armed struggle ${ }^{7}$.

\section{"Les Canadiens français sont-ils des colonisés?"}

It is significant that Memmi himself should also have addressed the question of whether or not Québec was a colony. In 1972, he discussed this issue in the postface to the Québecois edition of Portrait du colonisé; it was entitled "Les Canadiens français sont-ils des colonisés?". In the course of the 1960s, a number of Québécois writers and critics, including Pierre de Grandpré, Hubert Aquin and members of the editorial board of Parti pris had either corresponded with Memmi or visited him in Paris in order to seek his help in gaining French support for their cause ${ }^{8}$. Previously, he had been sympathetic to their aspirations, and had even dedicated the 1966 French re-edition of his classic work on colonialism "À mes amis canadiens français". But, he says, it was not until he had had

\footnotetext{
${ }^{7}$ Perhaps more than any other writer in Québec at the time, Hubert Aquin became fascinated by the psychology of the colonised subject, and in particular by that of the "écrivain colonisé". He developed this theme in a number of essays, including "Profession : écrivain" (1964); "L'art de la défaite" (1965); and "Littérature et aliénation" (1968).

${ }^{8}$ A decade earlier, Jacques Berque (1963, p. 50) had written an article lending his authority to the claim that Québec was a colony, yet it had not generated the kind of solidarity from abroad that the Québecois had hoped for.
} 
the opportunity to go to Québec and see the situation for himself that he felt capable of forming a judgement as to whether the Québécois were indeed 'colonised', as they claimed: "Ainsi, j'ai pu constater que les Canadiens étaient dominés, en effet, de plusieurs manières, et en tout cas qu'ils en souffraient" (Memmi, 1972, p. 138). Memmi argues that, although the term 'colonisation' usually suggests material and cultural poverty (at the time, the standard of living of most Québécois was not only higher than that of colonised Africans or Asians, but also comparatively higher than that of Europeans), it can still be applied to Québec'.

\section{Speak White}

Pierre Vallières's widely read book, Nègres blancs d'Amérique (1968), establishes an analogy between the situation of Black Americans and that of French Canadians. Whilst Memmi, as we have just seen, was to use the same analogy in 1972 in order to demonstrate the relativity of the notion of colonialism, Varlières's comparison - one that was already implicit in the expression "speak white" used by some English Canadians to signify their contempt for the language of French Canadians - stemmed from a desire to draw attention to what he regarded as North America's other great ethnic underclass, the minority of French Canadians whose history had also been forgotten and whose fate appeared to be of little interest to anyone :

C'est en voulant percer ce mur d'indifférence et de mépris que j'inventai, pour désigner les Québécois, le concept des nègres blancs d'Amérique. [...] Les Noirs américains furent les premiers, et pour cause, à saisir ce que pouvait être, sur les rives du Saint-Laurent, la condition particulière des Québécois francophones. $(1979$, p. 16)

From invoking the underprivileged sections of North American society, Vallières widens his discussion to encompass the colonial world, the archetype of oppression founded on racial difference. His book therefore draws inspiration from those countries which had recently broken free from their imperialist rulers in order to promote the 'anti-

\footnotetext{
${ }^{9}$ Memmi (1972, p. 139) backs up this assertion by drawing comparisons between the situation of French Canadians and the situation of Black Americans.
} 
colonial' cause in Québec, and to afford it the dignity of a righteous struggle against tyranny ${ }^{10}$.

After nearly three hundred pages devoted in large part to the demonstration that the Québécois are indeed a colonised people, Vallières remarks :

Cest devenu un ensemble de lieux communs de dire que le Québec est une colonie, une sous-colonie, une sous-sous-colonie, une triple colonie, etc. La 'dépendance' du Québec à l'égard de l'étranger est une constante de son histoire. [...] Car le Québec, depuis l'établissement d'un comptoir commercial à Québec par Champlain en 1608, a toujours été soumis aux intérêts des classes dominantes des pays impérialistes : d'abord, la France; puis l'Angleterre; et, aujourd'hui, les Etats-Unis. (1979, p. 276)

\section{Cahiers de la décolonisation du Franc-Canada}

Rather more radical was the tone of articles published by Les cahiers de la décolonisation du Franc-Canada, which first appeared in 1968 and continued into the late 1970s; here, the socio-economic and political aspects of the perceived colonisation were examined. Each page bears not altogether eloquent witness to the acrimony and anger directed towards the colonisers and their collaborators. The frequently repeated accusation that the Québécois people had been betrayed by an "élite clérico-bourgeoise" (the expression employed earlier by the Partipristes), and the denunciation of the inferiority complex of the Québécois vis-à-vis their language and their culture, at times gave way to emotive outbursts against "le fascisme colonial d'Ottawa" and "le génocide linguistique" (Saint-Denis, 1968a) which, it was claimed, was being practised by the powers-that-be.

However, expressions such as "Québec occupé", "un territoire occupe", "les maîtres étrangers", and, the inevitable charge of "complicité silencieuse des hauts cadres du clergé canadien-français", had become more or less common currency in Québécois social discourse; the term

${ }^{10}$ As he was to recall in the Preface to the second edition of Negres blancs d'Amérique (1979, p. 9) : "Heureusement pour nous, des damnés prirent les armes en Afrique, en Asie, en Amérique latine et réveillèrent dans nos corps fatigués dès l'enfance linstinct de lutte et de dignité. Nous nous sommes accrochés à ces guerres de libération avec le désespoir du dernier recours". 
"roi nègres" was also widely used to connote the subservience of 'local' leaders such as Duplessis and high-ranking members of the Church to the various colonial powers. When Vallières remarks that "Washington n'a qu'à lever le petit doigt pour mettre à genoux nos rois-nègres et nos cardinaux" $(1979$, p. 21$)$, he is merely reflecting an increasingly widely held view that Québec was, to all intents and purposes, living under foreign occupation, colonised politically, economically and culturally. Inevitably, the October Crisis only served to reinforce such sentiments : with the presence of the Federal armed forces in the province, the 'occupation' of Québec took on an altogether more sinister meaning't

\section{Beyond Metaphor}

The question that Memmi posed in 1972 coincides with the rise of the separatist movement, and the conviction among ordinary Québécois that theirs was a colonised people; some may have preferred the term 'dominated' or 'under occupation', but whatever the expression used, the underlying feeling of resentment remained and coloured social discourse. Contributing to the dissemination of this idea had been publications such as Le Colonialisme au Québec (1966) ${ }^{12}$ written by André D'Allemagne, the first president of the Rassemblement pour l'Indépendance Nationale, or RIN (founded in 1960), and Léandre Bergeron's Petit manuel d'histoire du Québec (1970), which were both premissed on the assertion that Québec had never ceased to be a colony (one colonising force had simply succeeded another over the centuries, from the French, to the English, to the present-day imperialists, the Americans). Thus, by the early 1970 s, whether or not these feelings were voiced explicitly, it was clear that the theme of colonisation had become a veritable topos in Québécois social discourse.

\footnotetext{
II Following the FLQ's kidnapping of the British Ambassador James Cross and murder of Pierre Laporte in October 1970, the War Measures Act was enforced in Québec which resulted in the arrest of hundreds of people, including the nationalist poet Gaston Miron. The social, political and artistic impact of these events is reassessed in Québec Studies (1990), volume 11, which devotes a special section to "Québec 1970 and its Aftermath".
}

12 "Depuis ses origines, le peuple canadien-français n'a jamais connu d'autre régime que le régime colonial. Ce fait a profondément marqué sa psychologie tout au cours de son histoire" (p. 17). 
As mentioned earlier, it had been a key element in the influential analyses of the Partipristes, which, furthermore, had linked the domination of the Church with the domination of the English : putting an end to the hitherto unchallenged rule of the clergy was seen as a prerequisite for achieving independence ${ }^{13}$. The two were simply different sides of the same coin. For Pierre Lefebvre, commenting in Parti pris, "la révolte contre le fait colonial et la contestation du joug moral et social de l'Église" $(1965$, p. 11) clearly went hand in hand.

\section{Secularisation as the Path to Decolonisation}

The rapid secularisation of Québécois society during the 1960s was heralded by many as the first step in the overall process of decolonisation that would eventually lead to independence for Québec ${ }^{14}$. For it was the notion of a separate state free from clerical control that had achieved the greatest consensus amongst the Francophones of the province. The third plank in the Partipristes's project - socialism - had signally failed to attract mass support over the past decade and, with the quelling of the FLQ which was finally dismantled in 1972, the possibility of a serious challenge from any revolutionary left-wing group was definitively laid to rest.

Instead, the Separatist movement gained in momentum, with a more individualist agenda, the emphasis being on bringing the living standards of the Québécois up to the same level as that of North Americans in general ${ }^{15}$.

\footnotetext{
${ }^{13}$ The Church is criticised not only for collaborating with the British colonisers, but taking on the role of 'colonisers' themselves. In dominating virtually all spheres of Québécois society, the clergy had established a powerful 'moral colony' whose mission was to preach the Catholic faith in North America and, in so doing, to preserve the culture and language of French Canadians.
}

${ }^{14}$ It is worth noting, however, that Parti pris denounced the illusion of freedom from the Church, a force it claimed that still held the Québecois in thrall and whose influence, if less overt, was all the more insidious. For Lalonde, however, "Au terme de son entreprise [that of Parti pris], le mouvement SÉCULARISATION-DÉCOLONISATION apparait très clair" (1979, p. 188).

${ }^{15}$ See, for example, Rioux (1974, p. 154-155). 
Whilst the renaming of the Province of Quebec as État du Québec may, for some, have served to emphasise the distance that still separated them from achieving nationhood, others could point to the actual gains that had been made in the past decade. These included the nationalisation of electricity companies (1962-63); the creation of a Ministry of Education (1964); the creation of CEGEPs, secondary colleges for pre-university students (1968) which replaced the cours classiques $^{16}$; the formation of the Parti Québécois (1968); the law on official languages (1969) ${ }^{17}$. Thus, 'decolonisation' had ceased to be a purely symbolic concept for those Separatists who, looking back on the fruits it had borne, could now hope for the final stage of this long drawnout process to be accomplished.

\section{The Language of Independence}

Allied to the secularisation of Quebec had been the development, following the Révolution tranquille, of a recognisably 'national' Québécois literature that no longer looked to France for inspiration ${ }^{18}$. The function of literary joual in promoting this search for a new, more authentic, identity, one that was free from the shackles of the French 'cultural colonialists', is well known ${ }^{19}$. Nevertheless, it is worth recalling that the use of various forms of Québécois French, ranging from Tremblay's joual (which represented the working-class sociolect of East Montréal) to

${ }^{16}$ Although the schools were now no longer controlled by the Church, they remained denominational institutions, whereas the CEGEPS were the first example of lay education.

${ }^{17}$ The setting up of a Royal Commission on Bilingualism and Biculturalism (1963-68) had, however, been hotly contested by the Separatists as an attempt to institutionalise cultural colonialism.

${ }^{18}$ See Rioux (1974, p. 177).

${ }^{19}$ The language issue has generated an on-going debate since the $1960 \mathrm{~s}$. For a useful overview of its repercussions on Québécois literature, see in particular Lise Gauvin, "Problématique de la langue d'écriture au Québec, de 1960 à 1975" in Langue française, September 1976. See also Présence Francophone, "Oralité et litterrature : France-Québec II", no. 31 (1988); the majority of articles are devoted to Tremblay's use of language in both theatre and fiction. 
Michel Garneau's linguistic experiments which produced an almost mythical "français québécois populaire" that was also "lyrique, dramatique" (Godin and Mailhot, 1988, p. 281), were part of a general trend which began in the late 1960 s. Virtually overnight, joual established itself as the accepted language of the theatre in Québec ${ }^{20}$, a practice that continued well into the $1980 \mathrm{~s}$, and whose legacy can still be detected today.

The vogue for translating into joual, which simultaneously sprang from this movement, is perhaps even more telling in terms of Québec's self-perception as a colony. Paul Lefebvre, for example, remarked :

Opter pour le langage populaire québécois comme langue de traduction permet souvent de conserver certaines caractéristiques inhérentes à l'original. [...] Pourtant, une certaine catégorie de spectateurs et de traducteurs-adaptateurs semblent bloqués en entendant un dialogue en québécois dans une pièce dont l'action se situe dans un autre pays. C'est donc qu'ils considèrent leur langue comme incapable de traduire un langage étranger de niveau équivalent. On a là une étonnante mais tangible relique d'un colonialisme culturel. (1978, pp. 46-47; italics added)

Such a consciously political use of joual can be regarded as part of a generalised decolonising strategy by Québec's Separatists who accused the French of cultural imperialism; according to this view, their influence was no less pervasive than that of the Americans in the economic sphere. Until the Révolution tranquille, Québec had of course depended largely on France for its films and television programmes as well as for its books, a dependence which, though far lesser today, has by no means disappeared. Furthermore, from the mid-60s onwards, there had been campaigns to improve the quality of the French spoken in Québec, the so-called "campagnes de Bon Parler". Tremblay was not alone in reacting indignantly to these attempts to impose 'le français de France' :

${ }^{20}$ The remarkable success of this attempt to oust standard French was, perhaps not surprisingly, largely confined to the field of drama, although the use of joul had first been experimented with in a couple of novels such as Jacques Renaud's Le cassé (1964) and Claude Jasmin's Pleure pas, Germaine (1965). 
Qu'on commence à donner à manger aux gens. On n'a pas d'affaire à leur dire comment parler. [...] Bien parler, c'est se respecter: c'est faux ça. Bien manger, c'est se respecter! Faut être colonisé pour sortir des slogans pareils... Les Français parlent plus mal que nous autres; tu verras jamais nulle part [en France] bien par]er c'est se respecter... (1973b, p. 6; italics added)

The forging of a new literary tradition via joual therefore vindicated claims that colonialism had stifled creativity in Québec, and that only a national consciousness, a national identity could foster a homegrown culture which would no longer be dependent on France. The very fact that joual, the language of the dispossessed, had now achieved a degree of literary recognition - earning at least some of the prestige that print automatically confers in the transfer from the spoken to the written - signalled the emergence of a more affirmative self-image for the Québécois, and reflected a new confidence and pride in themselves, following the transitional period of the $1960 \mathrm{~s}^{21}$.

\section{Towards a Post-Colonial Era}

Insofar as some of the expectations raised by the Révolution tranquille had been met, and the Québécois had entered a period of newly achieved social freedom, particularly after 1968 - thereby coinciding with what was going on in much of the West, a sign that at last, "le Québec [...] [venait] de 'sauter' du Moyen Age au XXe siècle" (1979, p. 27), as Pierre Vallières puts it - one can at least speak of a situation of partial 'decolonisation'.

This, then, constitutes the sociocultural context in which works of literature - translations included - published in Québec during the early 1970 s would have been produced. Needless to say, the discourse on the colonisation of Québec that has been surveyed thus far would have contributed considerably to the horizon of expectations (Jauss's Erwartungshorinzont) which Tremblay would have taken into account in

\footnotetext{
2I Paradoxically, whilst the decision to write in joual constituted a break with normative French, it also reflected a continued dependence on the English language, for this idiom contained a considerable proportion of anglicisms, and its morphology and syntax were often 'contaminated' by English usage. On this issue, see Miron's 1973 article, "Décoloniser la langue".
} 
his translation of Mistero buffo, either to confirm or to question its assumptions. It would seem that in order for a translated play to function as a play, to be 'performable', requires it to achieve a greater degree of acceptability vis-à-vis the audience than is necessary for other, less socially oriented, literary forms : following Henri Meschonnic, one can say that a dramatic text must be "structuré-reçu comme un texte" (Meschonnic, 1973, p. 307) ${ }^{22}$.

And this is what makes translation in the field of theatre so prone to the recycling of social discourse, so receptive to the deja dit, to the doxa of an age. Sociocriticism, appears to be a particularly effective tool for uncovering the discursive pattern underlying texts, as Annie Brisset's work in the area has shown so convincingly.

In order to appreciate the impact of anti-colonial discourse on Tremblay's version of Mistero buffo, it is first necessary to describe Fo's play, situating it in the time, and place, specific context of Italy's strong counter-culture of the late 1960s. Its strong ideological cast prompts one to look for correspondences with the target society, thereby raising the question of why this particular work was chosen for translation. The following overview suggests some possible reasons for such a choice, in the light of Mistero buffo's perceived bearing on the social and political situation that obtained in Québec in 1973, a time when great changes had been achieved but when the weight of their colonial history continued to haunt the Québécois. For, as Memmi pointed out: "En pleine révolte, le colonisé continue à penser, sentir et vivre contre et donc par rapport au colonisateur et à la colonisation" (1972, p. 124).

\section{Dario Fo's Mistero buffo and the Proletarian Revolution}

A highly original reworking of mediaeval mystery plays in a satirical vein, Mistero buffo afforded Italy's leading contemporary playwright, Dario Fo, the opportunity to attack the political power of his favourite target, the

\footnotetext{
${ }^{22}$ See Meschonnic's conception of what he terms a "traduction-texte" (as opposed to a "traduction-introduction"): "Si la traduction d'un texte est texte, elle est l'écriture d'une lecture-écriture, aventure personnelle et non transparence, constitution d'un langage-système dans la langue-système tout comme ce qu'on appelle ceuvre originale" (1973, p. 354).
} 
Church $^{23}$. Written in what Fo describes as the fifteenth-century dialect of the Po Valley - part-reinvention, part-archaeological exercise - Mistero buffo provided the perfect vehicle for Fo's Marxist views on popular culture and history. The introductions to each scene, the so-called interventi, serve to link the past, as represented in the play proper, to the present : in these interventions, Fo shows the relevance of the mediaeval world to the modern one, arguing that things have only changed in appearance since the power structures of society remain the same, with the proletariat (whether it be made up of farm- or factory-workers) still being exploited by the ruling classes (landowners, company directors and politicians alike). In addition, these workers are alienated, as their own culture has been submerged by that of the hegemony. Therein lies the significance of Fo's operation : to retrieve popular culture from its marginalised position, and to reappraise it, showing the enormous wealth and vitality of its traditions. Indeed, the play's narrative structure served to illustrate the Gramscian precept that progress - in other words, the workers' revolution - can only be achieved through an understanding of one's past. Thus, the ideological intention of Mistero buffo is, broadly speaking, to depict the class struggle through a symbolic representation of mediaeval society.

With the oppression of the people by both Church and state as the main subject of this play, Mistero buffo offers striking parallels with recent Québécois history. Translated into joual, and with all overt references to Marxism removed (the didactic introductions to each scene are excised in their entirety), Mistero buffo depicted a reality which would clearly have resonated with the target audience. In particular, Fo's contention, throughout Mistero buffo, that the clergy has always sided with the ruling classes, seems to correspond remarkably well with Québécois social discourse, as we saw earlier.

\section{Taking the Play to the Audience}

In 1973, when the Théâtre du Nouveau Monde, one of Montréal's leading institutional theatre companies, commissioned Tremblay to translate

\footnotetext{
${ }^{23}$ First presented in 1969 , the play was part of Fo's concerted attempt to create an 'alternative theatre circuit' which made entertainment accessible to ordinary people.
} 
Mistero buffo it seems probable that the choice of play was, at least in part, dictated by its use of religious material with a satirical intent (stories from the Gospel are revisited by Fo in order to put across his political message). Certainly, it is this aspect of Fo's many-layered work, that appears to be privileged in Tremblay's version, whilst other elements are either played down (for example, the emphasis on Christ as a revolutionary figure versus God as a repressive force; the poignancy of Christ's Passion; the mediaeval setting) or eradicated altogether (the celebration of Marxist humanitarian values; the role of the jongleur, and his latter-day counterparts, in transmitting the oral history of the people; the appropriation of popular culture by the bourgeoisie; the range of textual sources drawn on; the frequent references to theatrical devices, etc).

Given the nature of the material that Fo uses, his play may appear to be principally a parody of religion. Yet, as suggested above, his concerns are more wide-ranging, his methods more didactic. In translating Fo's social satire, Tremblay's primary objective seems to have been to ensure that Mistero buffo was topical. And this he achieved by focusing on the theme of the Church as a force of oppression and mystification, and by successfully adapting the comic treatment of this subject to appeal to a more specifically Québecois brand of humour. As is evidenced by the writings of the Partipristes and others, anti-clericalism had rapidly established itself as the new counter-ideology following the Revolution tranquille; furthermore, the repudiation of religion lay at the very heart of social discourse, constantly reinforced as it was by the media and the politicians in their desire to project the image of a modern - secular Québec. For this break with the century-old grip of the Church signalled a break with the past and, as such, was of considerable symbolic significance. At the same time, it represented for many Québécois an immeasurable sign of political progress, that first stage in the process of decolonisation which, if one were to believe the Partipristes, would prove to be decisive in the struggle to achieve full emancipation. This may well explain why Tremblay's version of Mistero buffo is far more overtly antireligious than Fo's play which targets the political role of the Church, rather than attacking religious beliefs per se : for the persistence of an anti-clerical attitude in the Québécois social discourse of the 1970s served 
as a constant reminder of the not-so-distant past, and of gains that could on no account be relinquished ${ }^{24}$.

\section{Tremblay's Transposition of Mistero buffo}

Whilst Tremblay has removed all explicit references to Marxism from his version of Mistero buffo, as observed earlier, the play's main theme remains that of oppression. At times, Tremblay appears to have followed the source text very closely; at others, there are major deviations which, at their most extreme, result in the opposite semantic information being conveyed. On the whole, though, one finds countless apparently minor changes and additions which all converge to produce a rather different political message from that transmitted in Fo's work.

A striking example of the extent to which the context of reception alone can be responsible for affecting one's reading of a target text is provided by Tremblay's "Le massacre des innocents". Although he has introduced no substantial changes, the depiction of the random killing of children by Herod's soldiers - the soldiers of the occupying Roman army - who have, in theory, been sent to murder only the first-born, but who in practice kill any baby they come across so as to ensure that Herod's orders are successfully carried out, takes on an altogether new dimension when viewed in a Quebécois setting. It offers strong parallels with the arbitrary arrests carried out during the 'military occupation' of Québec in October 1970, an event that would still have been fresh in the memories of most spectators. The decision by the federal government to send in troops to Québec, officially on the grounds of restoring order and quashing the FLQ, had been regarded by a large proportion of the Francophone population as an unprecedented breach of civil liberties, an over-reaction on the part of Ottawa, which was now revealing its true colours as a colonial power by employing repressive means to maintain its rule. Indeed, some believed that the federal forces were simply using the FLQ as a pretext for crushing nationalism :

Plusieurs dirigeants politiques ont tenté d'assimiler le PQ au FLQ. N'ont-ils pas de cette façon indiqué un des objectifs de la répression

${ }^{24}$ See, amongst others, Pierre Lefebvre (1965, p. 13). 
gouvernementale : briser le mouvement indépendantiste animé par le PQ? (Jean-Marc Piotte, 197I, p. 9)

The presence of the army in Québec underlined the continuing oppression of the Québécois by the English colonisers, who, it seemed to many, were only too happy to throw their weight around, rounding up and arresting hundreds of people, often on the slimmest of suspicions; their method of combatting terrorism, critics claimed, had itself created a reign of terror. It therefore seems likely that the (re-)enactment of army brutality on a Montréal stage would have evoked for the audience the perceived abuse of power by the police, less than three years earlier, in routing out the Felquistes.

The predicament in which Québécois policemen may at times have found themselves during the October Crisis, torn between their 'duty' and their own ethnic allegiances, is suggested by a small, but significant, addition in the target text. When the second soldier harrasses a woman who is carrying a lamb in the place of a child, the first soldier intervenes, telling him to leave her alone; and here, Tremblay inserts: "Jla connais, elle" (1973a, p. 3) ${ }^{25}$. Not allowing his compassion for her to interfere with his office, the first soldier quickly returns to the task in hand, spurring on the second soldier :

Est v'nue folle raide quand on y'a tué son p'tit. Envoye! Grouille! Y'en reste toute une gang à égorger... (Tremblay, 1973a, p. 3)

But the second soldier soon sickens of this endless bloodshed, rebelling against his part in it, and admitting his moral dilemma at having to kill children in peace-time. Additions such as "A'guerre, $y$ faut bien" and "ça fait partie d'la job!" (Tremblay, 1973a, p. 4) reinforce the sentiment of divided loyalties. Finally, the second soldier rejects the cynical 'code of honour' which the first soldier keeps reminding him of - the rhetoric that seeks to justify military massacres ${ }^{26}$ - and faces up to the unpalatable

${ }^{25}$ For the sake of clarity, references to Tremblay's translation are indicated by his, rather than Fo's name, contrary to standard practice. His version of Mistero buffo is therefore listed under "Tremblay 1973a" in the bibliographic references.

${ }^{26}$ For example, "Fais toé-s'en pas, bébé, pour c'te boucherie-là aussi tu vas en avoir des beaux discours rassurants des capitaines!" (Tremblay, 1973a, p. 4). 
truth of the current situation: "Mais c'te fois-là, c'est nos innocents à nous autres qu'on tue!" This departs somewhat from what Fo's soldier says: "Ma chí, as masa d'i inozenti..." $\left(1977\right.$, p. 33) ${ }^{27}$. By adding nos and à nous autres, Tremblay has transformed Fo's piece of anti-military propaganda - the war dead are all 'innocent', regardless of nationality -- into an allusion to the dualism inherent in the colonial universe : the soldier's internal conflict applies to all colonised soldiers or policemen who are inevitably called upon to use force against their own people ${ }^{28}$.

Appropriately, "Le massacre des innocents" is the opening scene of Tremblay's Mistero buffo : by evoking the recent unrest in Québec, it points to unresolved colonial tensions, and thereby sets the tone for the rest of the play which can be seen as a parable of French-Canadian oppression. For Tremblay has re-sited Mistero buffo on Québécois soil, an operation effected in large part by the use of joual ${ }^{29}$, and by a number of cultural adaptations. Noteworthy amongst these is the decision to substitute Fo's mediaeval villeyn for a "crotté" whose birthday happens to fall on June 24, the date of the Saint-Jean Baptiste which is celebrated as Québec's 'national' holiday.

\section{Portrait of the crotté}

The villeyn originally appeared in a scene entitled "La nascita del villano" ("The Birth of the Villeyn"). As if to underline his intention to radically transform the referential content of this scene, Tremblay renames it "La naissance du crotté", a change which openly declares his appropriation of the text, and which is all the more significant since it is the sole occasion in Mistero buffo when Tremblay has provided a new title for any of the

27 "But here we're killing innocents" (Fo, 1988, p. 21). Unless indicated otherwise, all translations into English are taken from Ed Emery's British version of Mistero buffo.

${ }^{28}$ See André D'Allemagne : "Dans la lutte contre les nationalistes québécois, la RCMP se contente de diriger la police colonisée. Ce sont les agents à gage de la police de Québec qui matraquent les manifestants à l'occasion du passage de la reine d'Angleterre" (1966, p. 145).

${ }^{29}$ As Bélair has remarked: "[...] le joual fait surgir un espace particulier du simple fait de son emploi [...]" (1973, p. 112). 
scenes. Thus, whereas in "La nascita del villano" we witness a savage piece of satire on the inhuman conditions that the feudal master imposed on the serf under the guise of a divinely ordained agrarian calendar, in "La naissance du crotté" a new catalogue of oppression is drawn up to correspond to the modern-day equivalent of the serf, the Québécois. Take, for example, the month of June; here, Fo has the Angel decree :

De zugno a tor scirese fait che ol vilan vaghi, su $i$ arbori de brugne, de peschi e de mugnaghi, ma innanz parché no debia sbafarse le piú bele faghe magnar la crusca che 'ag stopi le budele. $(1977, \text { p. } 93)^{30}$

Tremblay's version does away with the peasant context and with Fo's repeated references to food and bodily function that suggest something of the serfs daily struggle to survive. Instead, we are presented with an altogether different set of preoccupations :

En juin, quand ça s'ra sa fête, laisse-lé avoir un peu de fun, mais pas trop. Faut pas qu'y'oublie qu'y'est au monde pour trimer. Pis, surtout, lèvez des impôts sur tout c'qu'y fait, surtout su'l fun qu'y peut avoir! (p. 66)

The only outlet for cultural difference ("sa fête"), Tremblay seems to suggest, is in the form of religious celebrations such as the Saint JeanBaptiste processions with their allegorical carts and folkoric overtones ${ }^{31}$. Vallières, it is worth remembering, had denounced such events as colonial masquerades :

30 "In June, you must send the villeyn

To pick cherries from the trees,

As well as plums and peaches and apricots,

But first, so that he doesn't eat all the best ones, p. 61).

Make him eat dry bread, which will block up his bowels." (Fo, 1988,

${ }^{31}$ See also Fanon: "La culture nationale n'est pas le folklore où un populisme abstrait a cru découvrir la vérité du peuple. Elle n'est pas cette masse sédimentaire de gestes purs, c'est-à-dire de moins en moins rattachables à la réalité présente du peuple" (1974, p. 163). 
Tuons Saint Jean-Baptiste! Bralons le carton-pâte des traditions avec lequel on a voulu mythifier notre esclavage. $(1979$, p. 33)

According to Memmi, colonisers typically allow their colonised subjects to retain the traditional elements of their culture since the latter do not represent a threat to the established order. Particularly in the case of religious festivities, this submission to an ahistorical past encourages a certain apathy, a turning away from the (political) present :

[...] le colonisé conserve toutes ses fêtes religieuses, identiques à ellesmêmes depuis des siècles. Précisément, ce sont les seules fêtes religieuses qui, en un sens, sont hors du temps. Plus exactement, elles se trouvent à l'origine du temps de l'histoire, et non dans l'histoire. Depuis le moment où elles ont été instituées, il ne s'est plus rien passé dans la vie de ce peuple. Rien de particulier à son existence propre, qui mérite d'être retenu par la conscience collective, et fêté. Rien qu'un grand vide. (Memmi, 1972, p. 100; italics added) $)^{32}$

Pageantry, then, coupled with foreign jurisdiction ("des impôts sur tout c'qu'y fait") sums up the situation of the crotté who, in Tremblay's translation, stands at once for Québec, a fiefdom which has to content itself with an annual manifestation of nationalist sentiment, and the Québécois, vassals on whom are levied feudal (or federal) taxes.

Thus, whilst the mediaeval villeyn is portrayed by Fo as the prototype of proletarians worldwide, Tremblay's "crotté" is unequivocally rooted in Québécois reality, conjuring up the classic crotté - or underdog - portrayed in Jacques Renaud's Le cassé who connotes degradation and

\footnotetext{
${ }^{32}$ The notion that the Church exploited the more ritualistic aspects of religion in order to check the potential rebellion of the masses is found time and time again in the writings of, amongst others, the Partipristes. But it clearly had deep roots in Québécois social discourse, if the following extract from a letter which the Bishop of Québec wrote to the Govemor, Elgin, in July 1848, is anything to go by : "Votre Excellence peut compter sur la loyauté du peuple tant qu'il s'occupera de fêtes religieuses et qu'il s'acquittera de ses devoirs envers Dieu" (quoted in Dumont, 1993, p. 221).
} 
alienation ${ }^{33}$. The lowest of the low, the crotte is the pariah of Canadian society, according to Miron who is clearly speaking in the name of all Québécois when he asserts in a poem dating from 1970 : "Je suis crotté et dégoûtant devant les portes / [...] je n'ai pas eu de chance dans la baraque de vie" $\left(1994\right.$, p. 52) ${ }^{34}$. That crotte is another word for colonised is rendered explicit in Vallières's cry of "nous, les nègres : blancs; noirs, jaunes... les crottés de la terre!" $(1979$, p. 302$)$, which at once parodies and pays tribute to Fanon's key work on colonialism.

The significance of the term crotte in the social discourse of the period is borne out by its recurrence later on in the play, in "Boniface VIII". This scene presents the infamous mediaeval pope ostentatiously taking part in an almost regal procession during which he encounters Christ on his way to Golgotha. In an attempt to ingratiate himself with Christ who does not at first recognise him because of the way he is decked out - "J'avais oublié! Y faut que j'aye l'air pauvre! (Tremblay, 1973a, p. 100), Boniface removes all his finery, takes off his shoes, and even smudges his face in order to look the part of a pious Christian : "Me r'connais-tu, astheur! Je suis un de tes humbles serviteurs, pauvre, crotté [...]" (Tremblay, 1973a, p. 100). Since Fo's Bonifacio only says : "A te me ricognoset adess? A sont ol fiol de ti... umile [...]" (Fo, 1977, p. 117) one must question Tremblay's motivation in adding "un de tes [...] serviteurs", "pauvre", and especially "crotté". The latter word clearly functions as an "actualisateur" (Brisset, 1990, p. 228) which situates the action in Québec, and reinforces the isotopy of inferiority associated with the low social and economic status of the colonised Québécois that is built

${ }^{33}$ The pejorative term crotté was frequently used at the time to refer to 'life's losers', the poor and the marginalised, a description many working-class Québécois identified with.

${ }^{34}$ Valtières too, points to the poor social status of the Québécois, recalling those activities that are stereotypically associated with them - all designations which, in the $1960 \mathrm{~s}$, were virtually synonymous with 'French Canadian' : "nous [...], les crottés, les porteurs d'eau, les scieurs de bois, les cireurs de bottes, les manceuvres, les gratte-papier anonymes et mal payés [...], c'est par la force, et non par la résignation, la passivité et la peur, que nous deviendrons libres" (1979, p. 302),

35 "Do you recognise me now? I'm your humble son [...]" (my translation). 
up throughout the play ${ }^{36}$. The crotté is, of course, menial and poor by definition, but Tremblay's explicitation of this meaning corresponds to a certain "articulation présuppositionnelle" (Brisset, 1990, p. 252) that still characterised the social discourse of the early $1970 \mathrm{~s}$.

Furthermore, an incident that takes place later on in the same scene leaves the spectator in no doubt that the referent for crotte is always 'Québécois'. Desperate to demonstrate to Christ his brotherly love for humankind, Boniface sends for an ordinary Québécois, someone to be picked out of the crowd, ordering his assistant : "Va me chercher un quelconque crotté, vite!" (Tremblay, 1973a, p. 101) ${ }^{37}$. Tremblay then embroiders the narrative, adding :

Non, celui-là, y est pas assez crotté... va m'en chercher un pire, un laid, un affreux, un sale, un puant... vite! Mon standing baisse! Ah, tiens, lui va faire l'affaire... (1973a, p. 101)

Of course, the crescendo of adjectives is designed to heighten the comedy as we watch this self-centred, supercilious 'spiritual leader', a man incapable of concealing his utter disdain for the populace, whom he clearly regards as riff-raff. Yet, it also appears to fulfill a more serious function as Tremblay's addition here both underlines the abjectness ascribed to the crotté in Québécois social discourse and undermines it by his exaggeration. Thus, whilst acknowledging the existence of the clichéd image of the crotte, he also points to the distance between today's Québécois - who can laugh at their own self-portrait - and the colonised crotté of the past who had little to laugh about (there is nothing comic about the situation Renaud's cassé, Ti-Jean, finds himself in, to take a well-known example) ${ }^{38}$.

36 "[...] le malaise se traduit par l'auto-dénigrement, le mépris de soi, le 'né pour un p'tit pain'", writes Maheu (1966, p. 48) commenting on the misérabiliste selfperception long associated with the Québécois.

37 "Mamda a torme un fraite, svelto!" (Fo, 1977, p. 119). "Go fetch a monk, quick!" (my translation).

${ }^{38}$ See Memmi : "[...] le colonisé en révolte commence par s'accepter et se vouloir comme négativité. Cette négativité, devenant un élément essentiel de sa reprise de soi et de son combat, il va l'affirmer, la glorifier jusqu'ả l'absolu" (1972, p. 124). 


\section{The Colonial Master}

Where Fo anachronistically uses the term "padron" throughout Mistero buffo to refer to a feudal lord, or any member of the ruling class, thereby evoking the language employed during the political protests of the late 1960 s and 1970 s by the Italian Left, in particular by the trade unions, to refer to factory owners and heads of industry, Tremblay draws on a range of expressions which reflect a more natural Québecois usage (only occasionally resorting to "patron") : thus, he translates the same word by "gros écceurants", "grand boss", "maître", "gros boss", and even "le grand boss pis sa gang de pas-bons". Here the reference is no longer to a capitalist exploiter but to a colonial exploiter, with the "boss" or "maitre" in Tremblay's transposed tale automatically suggesting members of the Anglophone ruling class.

This transfer is yet another instance of the manner in which social discourse can impinge on translation decisions, decisions that are in no way haphazard; a different sociocultural context would clearly have offered the translator an altogether different range of discursive options. To take the example of "padron" cited above, it is instructive to compare the French version of Mistero buffo (which dates from the same year as Tremblay's) where the word "patron" is used consistently.

Tremblay's decision to emphasise or to insert references to the 'colonial situation' in Quebec is clearly not a random one. The discursive assumptions upon which translation - like any other form of social discourse - rests, suggest that it is likely to incorporate "une fonction doxologique" (1990, p. 312), to borrow Brisset's term. The success of a given translation may therefore depend as much on its ideological relevance to the target audience as on its intrinsic aesthetic merits. In the case of Tremblay's Mistero buffo. Fo's scheme of the proletarian struggle has been radically subverted to describe the Québécois colonial struggle, a subject of undisputed topicality at the time.

Tremblay's Mistero buffo can be seen as part of a continuing effort to raise consciences, to ensure that the struggle for selfdetermination be pursued by the Québécois, despite the gains already made : 
Je dis qu'aucun discours, aucune proclamation sur la culture ne nous détoumeront de nos tâches fondamentales qui sont la libération du territoire national, une lutte de tous les instants contre les formes nouvelles du colonialisme, un refus obstiné de nous entr'émerveiller au sommet. (Fanon, 1974, p. 165)

\section{Conclusion}

Inevitably, translations tend to privilege certain themes over others through the various 'adjustments', minor and major, that are introduced into a source text and result in what one might call an oriented reading. An explanation for this textual appropriation can be sought in the theory that translators internalise the rules governing what is linguistically, aesthetically and ideologically acceptable in a given society, and filter the foreign text accordingly; this "régulation", which is often unwitting, reveals the extent to which the translator, as mediator, is an accurate "relais des normes du discours social et de l'institution qui les instaure et les sanctionne" (Brisset, 1990, p. 199).

Thus, the topic of colonisation that was so central to Québécois social discourse during the 1960 s and early 1970 s provides us with a key with which to understand the world that is recreated in Tremblay's version of Mistero buffo; the transposition of Fo's mediaeval satire to a linguistically and socially contemporary Québec presents us with a universe divided between :

le monde du colonisé canadien-français, qui est le camp du droit et de Ia justice, et celui du colonisateur qui est celui de la richesse et de la force. (Michel Saint-Denis, 1968b)

The existence of this "manichéisme primaire qui fait du Canadian un mal absolu" (Chamberland, 1964, p. 59) offers a powerful illustration of the way the ideas of Fanon and Memmi were most passionately and selectively taken up in Québec during the 1960s, and rapidly assimilated into the ideology of the period. That the resulting portrait of the colonised Québécois should have found its way so visibly into Tremblay's Mistero buffo demonstrates the aptness of translated texts to draw on social discourse, a necessary strategy perhaps if they are to be sufficiently relevant to their new audiences. 


\section{References}

ANGENOT, Marc (1989). 1889: Un état du discours social. Longueuil, Les Éditions du Préambule.

AQUIN, Hubert (1995). "Profession: écrivain". Point de Fuite. Montréal, Bibliothèque québécoise (First published in Parti pris, January 1964).

Quinze.

(1977 [1965]). "L'art de la défaite". Blocs erratiques. Montréal,

(1977 [1968]). "Littérature et aliénation". Blocs erratiques.

Montréal, Quinze.

BÉLAIR, Michel (1973). Le norvel théâtre québécois. Montréal, Leméac.

BERGERON, Léandre (1970). Petit manuel d'histoire du Québec. Montréal, Éditions Québécoises.

BERMAN, Antoine (1995). Pour une critique des traductions : John Donne. Paris, Gallimard.

BERQUE, Jacques (1963). "Les révoltés du Québec". Parti pris, 1, 3, December.

BRISSET, Annie (1990). Sociocritique de la traduction. Theâtre et altérité au Québec (1968-1988). Longueuil, Québec, Les Éditions du Préambule.

CHAMBERLAIN, M. E. (1985). Decolonization. The Fall of the European Empires. Oxford, Basil Blackwell.

CHAMBERLAND, Paul (1964). "De la damnation à la liberté", 9-10-11. (Special summer issue).

D'ALLEMAGNE, André (1966). Le Colonialisme au Québec. Montréal, Les Éditions Renaud-Bray.

DUMONT, Fernand (1993). Genèse de la société québécoise. Montréal, Boréal. 
DUMOUCHEL, Thérèse (1967). "De Gaulle, un point tournant", in Parti pris, 5, 1, p. 27.

FANON, Frantz (1974 [1961]). Les Damnés de la terre. Paris, Maspero. (1974 [1952]). Peau Noire, Masques Blancs. Paris, Seuil.

FO, Dario (1977 [1969]) . Mistero buffo in Le commedie di Dario Fo, V. Torino, Einaudi.

(1973). Mistero buffo - Mystère bouffe -, Jonglerie populaire. (Bilingual text; translations prepared by the Centre de dramaturgie; ed. José Guinot). Verona, Bertani.

(1988). Mistero buffo. The Comic Mysteries. London, Methuen, 1988 (Translated by Ed Emery, with an introduction by Stuart Hood).

GAUVIN, Lise (1976). "Problématique de la langue d'écriture au Québec, de 1960 à 1975", Langue française, September.

(1988). "Oralité et littérature: France-Québec II", Présence francophone, 31 .

GODIN, Jean-Cléo and Laurent Mailhot (1988). Théâtre Québécois II. Montréal, Hurtubise HMH.

LALONDE, Michèle (1979). Défense et illustration de la langue québécoise. Paris, Seghers/Laffont.

LEFEBVRE, Paul (1978). "L'adaptation thêâtrale au Québec", Cahiers de théâtre Jeu, 9.

LEFEBVRE, Pierre (1965). "Croyance et révolution", Parti pris, 2, 8, April.

MAHEU, Pierre (1966). "Le dieu canadien français contre l'homme québécois". Parti pris, 4, 3, December.

MEMMI, Albert (1972 [1957]). Portrait du colonisé. Montréal, Les Éditions l'Étincelle. 
MESCHONNIC, Henri (1973). Pour la poétique II. Paris, Gallimard.

MIRON, Gaston (1993 [1970]). L'homme rapaillé. Montréal, Éditions Typo . (1993 edition includes "Décoloniser la langue" (1973), first published in Maintenant, 125, April; "Le Bilingue de naissance" (1974), first published in Maintenant, 134.)

Parti pris (1963). "Présentation", 1, 1, October. (1965). Éditorial, 2, 8, April. (1967). "L'indépendance au plus vite!", Éditorial, 4, 5-6.

PELLETIER, Jacques (1990/91). "Octobre 1970 et la transformation des rapports littérature/société depuis la révolution tranquille", Québec Studies, 11.

PIOTTE, Jean-Marc et al. (1971). Québec occupé. Montréal, Parti pris.

RENAUD, Jacques (1964). Le Cassé. Montréal, Parti pris.

RIOUX, Marcel (1974). Les Québécois. Paris, Éditions du Seuil.

SAINT-DENIS, Michel (1968a). "Nécessité d'un mouvement d'agitation". Les cahiers de la décolonisation du Franc-Canada 1, October [unnumbered].

(1968b). "Complicités coloniales". Les cahiers de la décolonisation du Franc-Canada, December [unnumbered].

TREMBLAY, Michel (1973a). Mistero buffo. Unpublished typescript. Special Collections, National Library, Ottawa.

Journal, 16-22 April.

(1973b). Interview with Tremblay by Nicole Bonin. Photo-

VALLIÈRES, Pierre (1979 [1968]). Nègres blancs d'Amérique. Montréal, Éditions Québec/Amérique. 
ABSTRACT : Decolonising Québec : Discursive Strategies in Michel Tremblay's Mistero buffo - During the 1960s and 1970s the concept of decolonisation was taken up by many Québécois intellectuals in their bid to promote the nationalist cause. Drawing on the theories of Albert Memmi and Frantz Fanon, such writers denounced what they regarded as the political, economic and cultural dependence of Québec. This article examines the way in which the topos of colonisation that permeated the social discourse of the period affected the translation and reception of Michel Tremblay's joual version of Mistero buffo. It seeks to demonstrate that Dario Fo's play has been transformed into a vehicle for challenging the perceived cultural imperialism of France and for asserting the importance of secularisation in the movement to "decolonise" Québec.

RÉSUMÉ : Décoloniser le Québec : stratégies discursives dans le Mistero buffo de Michel Tremblay — L'un des procédés utilisés par un certain nombre d'intellectuels québécois des années 1960 et 1970 dans leurs efforts de mise en valeur de la cause nationaliste consista à exploiter la notion de décolonisation. S'inspirant des théories d'Albert Memmi et de Frantz Fanon, ces auteurs dénonçaient ce qui leur apparaissait comme un état de dépendance à la fois politique, économique et culturelle du Québec. Cet article analyse comment le topos de la colonisation qui imprègne le discours social de l'époque est intervenu au niveau de la traduction et de la réception de la version en joual de Mistero buffo fournie par Michel Tremblay. Il cherche également à démontrer que l'on a fait de la pièce de Dario Fo un instrument de remise en question de ce que l'on percevait comme une forme d'imperialisme culturel de la part de la France en même temps qu'un moyen d'affirmer l'importance de la phase de sécularisation qu'avait connue le Québec dans le mouvement de "décolonisation" où il était engagé.

Jane Dunnett : École de traduction et d'interprétation, Faculté des arts, Université d'Ottawa, 70, av. Laurier est (401), C.P. 450, succursale A, Ottawa, Ontario, K1N 6N5, Canada. 